\title{
LIVER FUNCTION TESTS IN SURVIVORS OF HAEMOLYTIC DISEASE OF THE NEWBORN
}

\author{
BY
}

\author{
T. BIRD, A. J. CASSELLS-SMITH and W. WALKER \\ From the Department of Pathology, Newcastle General Hospital, and Children's Department, \\ Royal Victoria Infirmary, Newcastle upon Tyne
}

(RECEIVED FOR PUBLICATION JUNE 17, 1963)

Hepatocellular damage is sometimes a feature of severe haemolytic disease during the newborn period and might be expected to lead to permanent liver damage in some cases. Gerrard (1952), however, in a study of 226 cases of icterus gravis neonatorum, followed for more than five years, found little support for this hypothesis. His investigations included clinical examination, thymol turbidity tests and estimations of serum albumin and globulin. As part of a follow-up study of survivors of haemolytic disease of the newborn we therefore looked particularly for evidence of liver damage in a group of children who had had very severe haemolytic disease.

\section{Material and Method}

The children studied were born in Northumberland and Durham during the years 1948-1954 and were between 5 and 10 years of age at the time of follow-up. We consider that during this period full ascertainment of the disease in this community was achieved and that the cases are representative.

Three groups of children were selected for investigation.

Group 1. 135 children who had had very severe haemolytic disease of the newborn defined as follows: cord haemoglobin value less than 9 g./100 ml., or cord bilirubin value more than $6 \mathrm{mg}$. $/ 100 \mathrm{ml}$., or severe jaundice during the first week of life (bilirubin level more than $15 \mathrm{mg} . / 100 \mathrm{ml}$. if known), or birth weight $5 \frac{1}{2} \mathrm{lb}$. $(2,493 \mathrm{~g}$.) or less.

Group 2. 50 children from the same years who had less severe haemolytic disease of the newborn and on whom liver function tests were performed for comparison with the severely affected cases.

Group 3. 25 'normal' children of the same age-group. These were mainly children in hospital for surgical procedures such as herniorrhaphy, for the investigation of behaviour disorders, or for cardiac catheterization.

In addition to physical and audiometric examination, the results of which will be reported elsewhere, we asked specifically about the occurrence of jaundice after the neonatal period. We examined the children for clinical evidence of enlargement of liver or spleen, and blood was collected for liver function tests. Four empirical liver function tests and five serum enzyme assays were carried out, the tests being performed under routine conditions in the Department of Clinical Chemistry, Royal Victoria Infirmary, Newcastle upon Tyne.* In a few instances the amount of blood was insufficient for all tests to be performed, but in only two cases, both in Group 1, was it impossible to carry out any tests at all.

The severity of haemolytic disease in Groups 1 and 2 is shown in Table 1 with regard to birth weight, cord haemoglobin and bilirubin levels.

The relative severity is reflected in the treatment employed. Of the 133 cases tested in the severe group, 68 received exchange transfusion (six multiple exchange transfusion), 41 had simple transfusion (many in the period before exchange transfusion was established as the treatment of choice) and the 24 remaining did not receive transfusion. Of the 50 less severely affected, 16 were treated by exchange transfusion, three by simple transfusion, while 31 did not receive any active treatment.

\section{Results}

In no instance was a history obtained suggestive of liver damage nor was splenomegaly found on clinical examination in any child.

The percentile weight distribution in the severe group followed the normal pattern, $47 \%$ being below and $53 \%$ above the 50 percentile.

With regard to height there was some evidence that the children were under average height, $40 \%$ being above and $60 \%$ below the 50 percentile. The differences, however, were slight and mainly confined to children in the $25-50$ and $50-75$ percentiles;

\footnotetext{
*We are indebted to Professor A. L. Latner for permission to use these facilities, and to Mr. A. Mariner for the majority of the analyses.
} 
TABLE 1

SEVERITY OF HAEMOLYTIC DISEASE OF THE NEWBORN IN CASES STUDIED

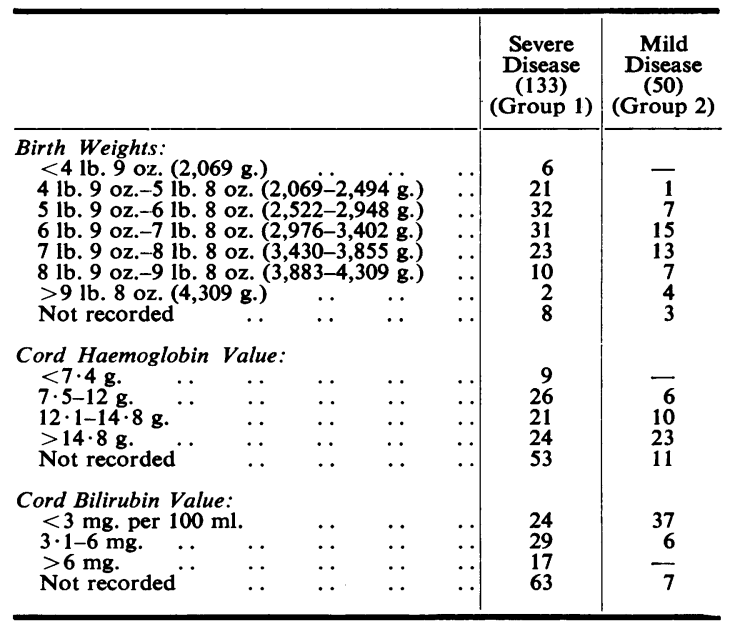

they could be explained, we thought, by the large proportion of premature infants included in the study.

The results of the liver function tests for the three groups are shown in Tables 2 and 3.

The results of the empirical liver function tests show a wider scatter than in normal adults, but only a small number were above the accepted normal adult range. There was no difference between the three groups.

With regard to serum enzyme levels, an appreciable number of children had abnormally high values. The alkaline phosphatase level was above 20 units in $10 \%$ of the children who had had severe disease but in only $4 \%$ of those with mild disease and in 'normal' children. Copper oxidase was highest in children who had had only mild disease and lowest in the 'normals'. Aldolase was high in about $14 \%$ of all cases and not raised predominantly in any particular group. Serum glutamate oxaloacetate transaminase (S.G.O.T.) levels were most increased in the severe and 'normal' groups while in only two cases was the serum glutamate-pyruvate transaminase (S.G.P.T.) level high, both being in the severe group.

Formal statistical comparison between the three groups does not reveal any significant difference except, surprisingly, that transaminase values are lower in the children with haemolytic disease than in the 'normals'.

For all cases, haemolytic disease of the newborn and otherwise, 160 abnormal liver function tests were recorded. One test only was abnormal in 111 children, two in 17 and three in five. In no child was there a consistent abnormal pattern in the majority of tests.

Of the five children with three abnormal findings, three had needed exchange transfusion while two had not required any treatment. Of those with two

TABLE 2

EMPIRICAL LIVER FUNCTION TESTS

\begin{tabular}{|c|c|c|c|c|c|c|c|}
\hline \multicolumn{2}{|c|}{ Cephalin Cholesterol Flocculation } & \multicolumn{2}{|c|}{ Thymol Flocculation } & \multicolumn{2}{|c|}{ Thymol Turbidity } & \multicolumn{2}{|c|}{ Zinc Sulphate } \\
\hline Reaction & No. of Cases & Reaction & No. of Cases & Units & No. of Cases & Units & No. of Cases \\
\hline $\begin{array}{c}0 \\
+ \\
++ \\
+++\end{array}$ & $\begin{array}{r}64 \\
59 \\
8 \\
2\end{array}$ & $\begin{array}{c}\text { Sever } \\
0 \\
+ \\
++ \\
+++\end{array}$ & $\begin{array}{c}\text { emolytic Disea } \\
80 \\
49 \\
4 \\
0\end{array}$ & $\begin{array}{c}\text { he Newt } \\
1 \\
2 \\
3 \\
4 \\
>4 \\
\text { N.T. }\end{array}$ & $\begin{array}{r}33 \text { cases) } \\
73 \\
39 \\
12 \\
4 \\
4 \\
1\end{array}$ & $\begin{array}{r}1 \\
2 \\
3 \\
4 \\
5 \\
6 \\
\text { N.T. }\end{array}$ & $\begin{array}{r}1 \\
26 \\
45 \\
22 \\
11 \\
27 \\
1\end{array}$ \\
\hline $\begin{array}{c}0 \\
+ \\
++ \\
+++\end{array}$ & $\begin{array}{r}30 \\
18 \\
2 \\
0\end{array}$ & $\begin{array}{c}0^{\text {Mil }} \\
+ \\
++ \\
++\end{array}$ & $\begin{array}{c}\text { emolytic Disea } \\
34 \\
16 \\
0 \\
0\end{array}$ & $\begin{array}{c}\text { Newb } \\
1 \\
2 \\
3 \\
4 \\
>4\end{array}$ & $\begin{array}{r}\text { (cases) } \\
12 \\
18 \\
11 \\
6 \\
3\end{array}$ & $\begin{array}{l}1 \\
2 \\
3 \\
4 \\
5 \\
6\end{array}$ & $\begin{array}{r}0 \\
2 \\
4 \\
4 \\
14 \\
26\end{array}$ \\
\hline $\begin{array}{c}0 \\
+ \\
++ \\
++\end{array}$ & $\begin{array}{r}20 \\
5 \\
0 \\
0\end{array}$ & $\begin{array}{c}0 \\
+ \\
++ \\
+++\end{array}$ & $\begin{array}{l}\text { 'Norma } \\
18 \\
4 \\
1 \\
2\end{array}$ & $\begin{array}{c}\text { cases) } \\
1 \\
2 \\
3 \\
4 \\
>4\end{array}$ & $\begin{array}{r}19 \\
3 \\
2 \\
0 \\
1\end{array}$ & $\begin{array}{l}1 \\
2 \\
3 \\
4 \\
5 \\
6\end{array}$ & $\begin{array}{l}6 \\
7 \\
5 \\
0 \\
6 \\
1\end{array}$ \\
\hline
\end{tabular}

Figures in bold indicate abnormal values. 
TABLE 3

SERUM ENZYME TESTS

\begin{tabular}{|c|c|c|c|c|c|c|c|c|c|}
\hline \multicolumn{2}{|c|}{ Alkaline Phosphatase } & \multicolumn{2}{|c|}{ Copper Oxidase } & \multicolumn{2}{|c|}{ Aldolase } & \multicolumn{2}{|c|}{ S.G.O.T. } & \multicolumn{2}{|c|}{ S.G.P.T. } \\
\hline $\begin{array}{l}\text { K.-A. } \\
\text { Units }\end{array}$ & $\begin{array}{c}\text { No. of } \\
\text { Cases }\end{array}$ & $\begin{array}{l}\text { Ravin } \\
\text { Units }\end{array}$ & $\begin{array}{l}\text { No. of } \\
\text { Cases }\end{array}$ & $\begin{array}{l}\text { Bruns } \\
\text { Units }\end{array}$ & $\begin{array}{l}\text { No. of } \\
\text { Cases }\end{array}$ & $\begin{array}{l}\text { Reitman and } \\
\text { Frankel Units }\end{array}$ & $\begin{array}{c}\text { No. of } \\
\text { Cases }\end{array}$ & $\begin{array}{l}\text { Reitman and } \\
\text { Frankel Units }\end{array}$ & $\begin{array}{l}\text { No. of } \\
\text { Cases }\end{array}$ \\
\hline $\begin{array}{r}5-10 \\
11-15 \\
16-20 \\
21-25 \\
>26 \\
\text { N.T. }\end{array}$ & $\begin{array}{r}10 \\
70 \\
35 \\
12 \\
1 \\
5\end{array}$ & $\begin{array}{r}100 \\
200 \\
300 \\
400 \\
500 \\
>\mathbf{5 0 0} \\
\text { N.T. }\end{array}$ & $\begin{array}{c}\text { Severe Hae } \\
1 \\
19 \\
50 \\
30 \\
15 \\
7 \\
11\end{array}$ & $\begin{array}{c}\text { Disea } \\
<4 \\
4-6 \\
6-8 \\
8-9 \\
>9 \\
\text { N.T. }\end{array}$ & $\begin{array}{c}\text { Newb } \\
11 \\
22 \\
35 \\
26 \\
17 \\
22\end{array}$ & $\begin{array}{c}\text { (133 cases) } \\
<10 \\
10-15 \\
16-20 \\
21-30 \\
>30 \\
\text { N.T. }\end{array}$ & $\begin{array}{r}3 \\
11 \\
27 \\
59 \\
29 \\
4\end{array}$ & $\begin{array}{c}<10 \\
10-15 \\
16-20 \\
21-30 \\
>30 \\
\text { N.T. }\end{array}$ & $\begin{array}{r}61 \\
37 \\
19 \\
8 \\
2 \\
6\end{array}$ \\
\hline $\begin{array}{r}5-10 \\
11-15 \\
16-20 \\
21-25 \\
>26 \\
\text { NT. }\end{array}$ & $\begin{array}{r}4 \\
19 \\
24 \\
0 \\
2 \\
1\end{array}$ & $\begin{array}{r}100 \\
200 \\
300 \\
400 \\
500 \\
>\mathbf{5 0 0} \\
\text { N.T. }\end{array}$ & $\begin{array}{c}\text { Mild Haer } \\
0 \\
3 \\
10 \\
14 \\
9 \\
11 \\
3\end{array}$ & $\begin{array}{c}\text { Diseas } \\
4 \\
4-6 \\
6-8 \\
8-9 \\
>9 \\
\text { N.T. }\end{array}$ & $\begin{array}{c}\text { Newb } \\
6 \\
11 \\
17 \\
2 \\
6 \\
8\end{array}$ & $\begin{array}{c}\text { (50 cases) } \\
<10 \\
10-15 \\
16-20 \\
21-30 \\
>30 \\
\text { N.T. }\end{array}$ & $\begin{array}{r}0 \\
10 \\
14 \\
24 \\
2 \\
0\end{array}$ & $\begin{array}{r}<10 \\
10-15 \\
16-20 \\
21-30 \\
>30 \\
\text { N.T. }\end{array}$ & $\begin{array}{r}12 \\
24 \\
12 \\
2 \\
0 \\
0\end{array}$ \\
\hline $\begin{array}{r}5-10 \\
11-15 \\
16-20 \\
21-25\end{array}$ & $\begin{array}{r}3 \\
13 \\
8 \\
1\end{array}$ & $\begin{array}{l}100 \\
100 \\
300 \\
400 \\
500\end{array}$ & $\begin{array}{r}0 \\
4 \\
15 \\
5 \\
1\end{array}$ & $\begin{array}{c}\text { 'Norm } \\
<4 \\
4-6 \\
6-8 \\
8-9 \\
>9\end{array}$ & $\begin{array}{c}\text { cases) } \\
7 \\
7 \\
6 \\
2 \\
3\end{array}$ & $\begin{array}{c}<10 \\
10-15 \\
16-20 \\
21-30 \\
>30\end{array}$ & $\begin{array}{r}0 \\
0 \\
2 \\
8 \\
15\end{array}$ & $\begin{array}{r}<10 \\
10-15 \\
16-20 \\
21-30 \\
>30\end{array}$ & $\begin{array}{r}3 \\
10 \\
4 \\
8 \\
0\end{array}$ \\
\hline
\end{tabular}

Figures in bold indicate abnormal values. N.T. $=$ Not tested.

TABLE 4

SERUM ENZYME LEVELS IN NORMAL CHILDREN AND ADULTS*

\begin{tabular}{|c|c|c|c|c|c|c|c|c|}
\hline \multirow[b]{2}{*}{ S.G.O.T. } & \multirow[b]{2}{*}{$\cdots$} & \multirow[b]{2}{*}{$\cdots$} & & \multirow[b]{2}{*}{$\cdots$} & \multicolumn{2}{|c|}{ Range } & \multirow{2}{*}{$\begin{array}{l}\text { Mean } \\
19 \\
30 \cdot 4\end{array}$} & \multirow{2}{*}{ 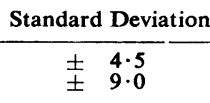 } \\
\hline & & & & & $\left\{\begin{array}{l}\text { Adult } \\
\text { Child }\end{array}\right.$ & $\begin{array}{l}12-36 \\
17-53\end{array}$ & & \\
\hline S.G.P.T. & . & . & . & . & $\left\{\begin{array}{l}\text { Adult } \\
\text { Child }\end{array}\right.$ & $\begin{array}{l}4-24 \\
9-29\end{array}$ & $\begin{array}{l}12 \\
16\end{array}$ & $\begin{array}{l} \pm \quad 4 \cdot 2 \\
\pm \quad 5.9\end{array}$ \\
\hline \multicolumn{2}{|c|}{ Serum oxidase } & $\cdots$ & . & . & $\left\{\begin{array}{l}\text { Adult } \\
\text { Child }\end{array}\right.$ & $\begin{array}{l}206-365 \\
237-523\end{array}$ & $\begin{array}{l}294 \\
395\end{array}$ & $\begin{array}{l} \pm 39 \\
\pm 76\end{array}$ \\
\hline \multicolumn{2}{|c|}{ Serum aldolase } & $\cdots$ & . & . & $\left\{\begin{array}{l}\text { Adult } \\
\text { Child }\end{array}\right.$ & $\begin{array}{l}2 \cdot 3-8 \cdot 8 \\
1 \cdot 5-9 \cdot 3\end{array}$ & $\begin{array}{l}5 \cdot 7 \\
4 \cdot 85\end{array}$ & $\begin{array}{ll} \pm & 1 \cdot 74 \\
\pm & 2 \cdot 5\end{array}$ \\
\hline
\end{tabular}

* Adult values taken from Rowell and Smith (1959).

results abnormal, seven had been treated by exchange transfusion, eight had received no treatment and two were 'normal' children.

The accepted normal adult values cannot be applied to enzyme tests performed in children and in Table 4 we have shown the values for normals in the present series compared with 50 normal adults. The tests in each group were performed in the same laboratory using the same techniques although in different chronological periods.

Two children are of particular interest.

Case 1. When tested at the age of 6 years gave the following results, cephalin cholesterol flocculation +++ , thymol flocculation ++ , thymol turbidity 6 units, zinc sulphate 8 units, alkaline phosphatase
33 units, copper oxidase 619 units, aldolase 18 units, S.G.O.T. 94 units and S.G.P.T. 350 units. This patient had been in contact with infective hepatitis and within two weeks his mother and brother developed infective hepatitis. The patient himself never became jaundiced, but the liver function tests repeated six months later were normal with the exception of a serum oxidase level of 475 units.

Case 2. The other child gave no history of contact with hepatitis, but all the empirical tests were abnormally high, although the enzyme values were within normal limits. At the time of this test the child was not well, although no specific diagnosis was ever made. When tested six months later normal values were obtained, except that the alkaline phosphatase level was 21 units. 
In these two cases we consider that the abnormal values suggested an infective illness at the time of the tests and did not indicate permanent liver damage.

\section{Discussion}

Pathological changes in the liver of cases of haemolytic disease of the newborn have frequently been described. Hawksley and Lightwood (1934) reported cirrhosis, of varying degree, in seven out of nine cases who lived beyond 5 weeks, but not in six who died earlier.

Henderson (1942) described established cirrhosis in macerated foetuses said to have haemolytic disease of the newborn. He also stated that nearly one-third of his cases of icterus gravis neonatorum showed evidence of fibrosis, usually following centrilobular necrosis, if they survived for more than a few weeks. These findings were supported in part by Gilmour (1944), Lightwood and Bodian (1946) and Craig (1950). Philpott, Hendelman and Primrose (1949) suggested that liver damage, which might be protracted, occurred in all cases of haemolytic disease of the newborn; he, therefore, advocated the use of methionine in immunized mothers and affected infants. Craig and Landing (1952), in a review of 20 cases of neonatal 'giant-cell' hepatitis, which they considered viral in origin, noted that three also had haemolytic disease of the newborn, and Ehrlich and Ratner (1955) thought that two similar cases were due to isoimmunization and not to virus.

Although early and severe jaundice is a feature of severe haemolytic disease of the newborn, this is usually thought to be due to increased haemolysis in the presence of a specific defect of bilirubin conjugation rather than to liver damage. Craig, Gellis and Hsia (1955), in a review of 98 cases of cirrhosis in infancy and children, found only two associated with haemolytic disease of the newborn and considered that hepatitis was the probable cause. They believed that hepatitis, whether viral or 'neonatal', was a common cause of cirrhosis, apart from true obstructive causes such as atresia of the bile-ducts.

Obstructive jaundice sometimes occurs in infants with haemolytic disease of the newborn and this is currently thought to be due to hepatocellular damage rather than to blocking of bile-ducts by inspissated bile. Harris, Andersen and Day (1954) described 16 cases of prolonged obstructive jaundice in a group of 231 children with haemolytic disease of the newborn. Three died at the end of one month, another at 2 years, but the remaining 12 were found to be healthy at the age of 5 years despite the fact that in eight, liver biopsy in the first six months of life had revealed excess haemopoiesis, giant-cell change and slight increase of fibrous tissue. Hsia and Gellis (1953) found no evidence of permanent liver damage in 23 such cases and Bowden and Donohue (1955) reviewing jaundice in the neonatal period considered that many reports of cirrhosis due to haemolytic disease of the newborn were not acceptable, as proof of immunization was often lacking. This seems to apply to the cases published by Braid and Ebbs (1937) and Drummond and Watkins (1946). It may be that these familial cases were examples of the condition described as congenital hepatic fibrosis (Kerr, Harrison, Sherlock and Walker, 1961). Bowden and Donohue felt that permanent liver damage due to haemolytic disease of the newborn was extremely rare even in cases with an obstructive element and considered that viral hepatitis, neonatal hepatitis and congenital biliary atresia were much more likely causes. Like most workers, they accept the presence of multinucleated giant-cell changes in the liver of infants as a non-specific reaction to injury.

In our experience the majority of deaths due to haemolytic disease of the newborn have occurred early in the neonatal period. Autopsy findings in the liver consist mainly of enlargement, congestion, fatty change, deposition of bile pigment and haemosiderin in hepatic cells and increase in haemopoiesis which may be very intense but unlikely to interfere mechanically with liver function. During the years from which these cases were drawn only seven infants showed definite histological evidence of liver Cell damage. Two treated by exchange transfusion died in the first two days. In both the liver was enlarged and degenerative changes sometimes amounting to centrilobular necrosis were widespread. Another infant who died at 16 days due to widespread haemorrhage, showed scattered liver cell changes of degeneration and necrosis, with occasional multinucleated cells. The four remaining infants died during the first five months of life. Two were slightly jaundiced but showed definite cirrhosis, with an increase of interlobular and portal fibrous tissue. A third was not jaundiced and showed no increase of fibrous tissue but moderate giant-cell change was present. The fourth showed focal degenerative changes and slight giant-cell change. In all these cases there was an excess of haemopoiesis and the altered cells contained abundant bile pigment with relatively little haemosiderin. These four cases have already been described by Bird (1953). In a study of kernikterus due to haemolytic disease or prematurity he found no evidence of liver damage in 46 additional infants who died within the first two weeks. 
Severe jaundice is often the most striking feature of haemolytic disease of the newborn but its presence is not always precisely related to the severity of the disease as assessed on the basis of cord haemoglobin value. Severity of jaundice is also dependent on the maturity of the infant and may be modified by treatment. Those infants who are so severely affected as to die in the first weeks of life may show histological changes in the liver, the significance of which is not fully understood and which could possibly be due to other features such as anoxia or circulatory disturbances. Similar changes may also be seen in infants of the same age-group who do not have haemolytic disease of the newborn. If the infant survives, jaundice, no matter how severe, clears completely and permanently. Those infants who have a phase of obstructive jaundice may remain jaundiced for a matter of weeks but in these also complete recovery is the rule. However, if death occurs in the first six months of life the histological picture may be that of 'giant-cell hepatitis' which may be a non-specific response to 'injury'.

Whether permanent liver damage ever occurs leading to cirrhosis is not proven because it is always possible that coincidental factors may have been operating. One infant in our care but not included in the present series died at the age of $4 \frac{1}{2}$ months with advanced cirrhosis, but she was also thought to have cytomegalic inclusion disease. Another boy of 7 years who had only moderately severe haemolytic disease of the newborn now has splenomegaly, the nature of which has not yet been established.

The survivors described in the present article all have had haemolytic disease of varying severity, but follow-up study has shown no evidence of permanent liver damage as assessed by clinical examination and within the limitations of the liver function tests used. It could be argued that the tests performed were not ideal, but it was not considered justifiable to carry out bromsulphthalein excretion tests in these children. Although some of the patients had probably had obstructive episodes in the neonatal period, the records were not adequate to study this aspect and a follow-up study of patients of this type is currently being carried out.

Although 160 out of 1,810 tests performed gave abnormal results as judged by normal adult values, the abnormalities were of mild degree, especially as children show a wider range of normal. Moreover, they were not restricted to any particular group of children and it was exceptional for a child to have more than one abnormal test. Two children who showed grossly abnormal liver function tests were shown to have hepatitis or other infection and the tests reverted to normal within six months.

We, therefore, conclude that permanent liver damage is unlikely to be a sequela of haemolytic disease, even when severe, but further study of infants with the 'inspissated bile syndrome' is required.

\section{Summary}

One hundred and thirty-three infants with severe haemolytic disease of the newborn and 50 with less severe haemolytic disease of the newborn were followed up at the age of 5 to 10 years. No evidence of permanent liver damage was detected on clinical examination or by a battery of four empirical and five serum enzyme tests.

The values of these tests in 25 normal children of this age-group are reported.

\section{REFERENCES}

Bird, T. (1953). Kernicterus. M.D. Thesis, University of Durham. Bowden, D. H. and Donohue, W. L. (1955). Jaundice in the neonatal period. Amer. J. med. Sci., 230, 305.

Braid, F and Ebbs, J. H. (1937). Atrophic cirrhosis of the liver following icterus gravis neonatorum, with pathological report. following icterus gravis neona

Craig, J. M. (1950). Sequences in the development of cirrhosis of the liver in cases of erythroblastosis fetalis. Arch. Path., $49,665$.

, Gellis, S. S. and Hsia, D. Y-Y. (1955). Cirrhosis of the liver in infants and children. A.M.A. Amer. J. Dis. Child., 90, 299.

and Landing, B. H. (1952). Form of hepatitis in neonatal period simulating biliary atresia. Arch. Path., 54, 321.

Drummond, R. J. and Watkins, A. G. (1946). The Rh factor and hepatomegaly and splenomegaly in children and adolescents. Brit med J 984

Ehrlich, J. C. and Ratner, I. M. (1955). Congenital cirrhosis of the liver with kernicterus. Amer. J. Path., 31, 1013.

Gerrard, J. (1952). Icterus gravis and cirrhosis of the liver. Brit. med. J., 1, 1385.

Gilmour, J. R. (1944). Erythroblastosis foetalis. Arch. Dis. Childh., $19,1$.

Harris, R. C. Andersen, D. H. and Day, R. L. (1954). Obstructive jaundice in infants with normal biliary tree. Pediatrics, 13, 293.

Hawksley, J. C. and Lightwood, R. (1934). A contribution to the study of erythroblastosis: Icterus gravis neonatorum. Quart. J. Med. n.s., 3, 155 .

Henderson, J. L. (1942). A fourth type of erythroblastosis foetalis showing hepatic cirrhosis in the macerated foetus. A report of three cases. Arch. Dis. Childh., 17, 49.

Hsia, D. Y-Y. and Gellis, S. S. (1953). Prolonged obstructive jaundice in infancy. III. Liver function tests. A.M.A.Amer. J. Dis. Child., 85, 13.

Kerr D N. S Harrison, C. V., Sherlock, S, and Walker, R. Milnes (1961). Congenital hepatic fibrosis. Quart. J. Med., n.s., 30, 91.

Lightwood, R. and Bodian, M. (1946). Biliary obstruction associated with icterus gravis neonatorum. Arch. Dis. Childh., 21, 209.

Philpott, N. W., Hendelman, M. and Primrose, T. (1949). The use of methionine in obstetrics. Amer. J. Obstet. Gynec., 57, 125.

Rowell, N. R. and Smith, A. J. (1959). Multiple serial enzyme studies in acute myocardial infarction. Brit. med. J., 2, 459. 